\title{
Evaluasi Produksi dan Persentase Karkas Itik Peking dengan Pemberian Pakan Fermentasi Probiotik
}

\author{
Evaluation Production and Percentage of Peking Duck Carcass of Feed \\ Fermentation Probiotic \\ (Sukirmansyah, Muhammad Daud, HerawatiLatif) ${ }^{1}$ \\ ${ }^{1}$ Program StudiPeternakanFakultasPertanianUniversitasSyiah Kuala
}

\begin{abstract}
Abstrak: Penelitian tentang produksi dan persentase karkasitik Peking dengan pemberian pakan fermentasi probiotik dalam ransum itik Peking telah dilaksanakan di peternakan masyarakat Gampong Mireuk Lamreuduep, Kecamatan Baitussalam, Aceh Besar selama 2 bulan yang berlansung dari tanggal 1 Juli sampai 31 Agustus 2015. Tujuan penelitian ini untuk mengetahui pengaruh pemberian pakan fermentasi probiotik terhadap produksi dan persentase karkas itik Peking. Penelitian ini menggunakan 80 ekor itik peking umur 1 hari (DOD). Rancangan penelitian yang digunakanadalahrancanganacaklengkap (RAL) yang terdiridari 4 perlakuandan 4 ulangan. Setiap ulangan merupakan unit percobaan yang terdiri dari 5 ekor itik peking. Perlakuan pakan fermentasi probiotik yang diberikan adalah $\mathrm{R}_{1}$ (kontrol); $\mathrm{R}_{2}(10 \%) ; \mathrm{R}_{3}(12,5 \%) ; \mathrm{R}_{4}(15 \%)$. Parameter yang diamati adalah: berat hidup, berat karkas, persentase karkas, bobot potongan karkas (dada, sayap, paha, dan punggung) dan persentase potongan karkas (dada, sayap, paha, dan punggung). Hasil penelitian menunjukkan bahwa pemberian pakan fermentasi probiotik dalam ransum itik Peking berpengaruh nyata $(\mathrm{P}<0,05)$ terhadap potongan karkas sayap, dan persentase potongan karkas paha, namun tidak berpengaruh nyata terhadap berat hidup, berat karkas, persentase karkas, persentase potongan karkas dada, potongan karkas sayap, potongan karkas punggung. Berdasarkan hasil penelitian dapat disimpulkan bahwa pemberian pakan fermentasi probiotik dalam ransum itik Peking dengan level berbeda menunjukkan pengaruh positif terhadapberat hidup, berat karkas, berat potongan karkas (dada, paha, punggung) dan persentase potongan karkas (dada, danpunggung).
\end{abstract}

Kata kunci :fermentasi, probiotik, itikpeking, karkas, danpersentasekarkas

\begin{abstract}
The research on production and percentage of peking ducks carcass by fermented probiotic feeding in rations of peking duck has been conducted at the community farm in Gampong Mireuk Lamreuduep, Baitussalam, Aceh Besar for two months. The purpose of this study is to determine the effect of feeding fermented probiotic on the production and percentage of peking duck carcass. The study used 80 peking ducklings (DOD). The design of this study is a completely randomized design (RAL), which consists of 4 treatments and four replications. Each replications is an experimental unit which is consisting of 5 peking ducks. Given fermented probiotic treatment is R1 (control); R2 (10\%); R3 (12.5\%); R4 (15\%). The measured parameters were: live weight, carcass weight, carcass percentage, carcass weight in pieces (breast, wing, thigh, and back) and the percentage of carcass pieces (breast, wing, thigh, and back). The results of the study showed that fermented prabiotics feeding in peking duck ration significantly effect $(\mathrm{P}<0.05)$ toward carcass pieces of wings, and the percentage of carcass thigh pieces, but it did not significantly affect live weight, carcass weight, carcass percentage, percentage of carcass chest pieces, pieces of carcass wing, pieces of carcass back. Based on the results of this study, it can be concluded that fermented probiotics feeding in ration of peking duck in different levels showed a positive effect on live weight, carcass weight, carcass weight pieces (breasts, thighs, back) and percentage carcass pieces (chest and back).
\end{abstract}

Keywords: probiotics, peking duck, carcass 


\section{PENDAHULUAN}

Pengembangan usaha peternakan itik pedaging di Indonesia saat ini masih mengalami berbagai kendala.Salah satu kendala dalam pengembangan usaha peternakan khususnya ternak itik yaitu penyediaan pakan yang kurangberkualitas baik. Kendala dalam penyediaan pakan meliputi ketersediaan bahan baku pakan yang bernilai nutrisiharga mahal terutama sumber protein dalam pakan yang masih impor seperti tepung ikan dan bungkil kedelai. Pada usaha peternakan biaya pakan mencapai 60\%-70\% dari total biaya produksi (Rasyaf, 1994). Untuk menekan biaya pakan tersebut perlu dilakukan usaha untuk mencari sumber bahan baku yang lebih murah, mudah didapat, bergizi baik, tetapi tidak bersaing dengan kebutuhan manusia. Untuk itu perlu digali potensi bahan pakan yang banyak tersedia dalam negeri. Apabila biaya pakan dapat ditekan, maka akan meningkatkan keuntungan peternak dan sekaligus membantu mengembangkan usaha pemeliharaan itik pedaging.

Itik Peking merupakan ternak itik yang berasal dari daratan Tientsien, Cina. Itik Peking pertama kali didatangkan dari Cina ke Amerika Serikat pada tahun 1870. Popularitas itik Peking ini dikenal sebagai penghasil daging diseluruh dunia,baik dibelahan utara maupun dibelahan selatan,termasuk didaerah tropis(Murtidjo, 1998). Dalam bidang pengembangbiakan itik Peking disilangkan dengan itik Alyesbury. Didaerah Indonesia itik peking disilangkan dengan itik kaki Campbell atau yang lebih dikenal dengan itik Mojosari dan itik lainnya.

Karkas adalah daging bersama tulang yang telah terpisah dari kepala dengan sampai batas pangkal leher dan dari kaki hingga batas lutut serta dari isi rongga perut (Kamran et al., 2008). Karkas merupakan bagian tubuh unggas yang sudah dilakukan penyembelihan secara halal, pencabutan bulu, dan pengeluaran jeroan, tanpa kepala, leher, kaki, paru-paru, dan ginjal (Standar Nasional Indonesia, 2009).Menurut Soeparno (1994)karkas merupakan hasil utama pemotongan ternak yang memiliki nilai ekonomis tinggi.

Probiotik merupakan suplemen makanan yang berupa bakteri hidup non patogen, tidak bersifat toksin, tahan terhadap asam lambung dan dapat berkoloni pada usus besar (kolon). Jenis bakteri probiotik yang paling dikenal adalah golongan bakteri asam laktat dan bifidobacteria. Keuntungan probiotik adalah memiliki kemampuan untuk mencegah reaksi bakteri patogen, dengan merangsang aktivitas peristaltik usus, detoksifikasi beberapa komponen makanan yang merugikan dan mengeluarkannya, mensuplai enzim untuk membantu mencerna beberapa bahan makanan.

\section{METODE PENELITIAN}

Penelitian ini dilaksanakan di lokasi peternakan masyarakat Gampong Miruek Lamreudeup Kecamatan Baitussalam, Aceh Besar. Penelitian berlangsung selama 2 bulan terhitung daritanggal 1 JuniSampai 31 Agustus 2015 


\section{Materi Penelitian}

Penelitian ini menggunakan sebanyak 80 ekor itik Peking, produksi PT. Charoen Phokphan. Itik tersebut dipesan melalui salah satu poultry shop yang ada di Banda Aceh.

\section{RANSUM PENELITIAN}

PenelitianawalmenggunakanransumdasarberuparansumkomersilyaituR511untuku mur minggu(starter)tanpaadaperlakuanapapundanselanjutnyadigunakanbahan pakan yang disusunberdasarkan formulasikemudian dilakukan fermentasi denganmenggunakan bakteri probiotik.Probiotik yang digunakansebanyak 10 $\mathrm{ml} /$ liter, $12,5 \mathrm{ml} /$ liter dan $15 \mathrm{ml} /$ liter air yang dicampurkedalampakanransum basal.Perlakuan pakan fermentasi diberikan padaitikpeking berumur 5 8minggu(grower/finisher). Ransumperlakuan yang digunakanadalahsebagaiberikut:

$\mathrm{R}_{1}=$ Ransum basal $100 \%$ (kontrol).

$\mathrm{R}_{2}=$ Ransum fermentasi probiotik $10 \mathrm{ml} /$ liter air.

$\mathrm{R}_{3}=$ Ransum fermentasi probiotik $12,5 \mathrm{ml} /$ liter air.

$\mathrm{R}_{4}=$ Ransum fermentasi probiotik $15 \mathrm{ml} /$ liter air

Tabel 1. Komposisi dan Kandungan Nutrisi Ransum Basal

\begin{tabular}{|c|c|c|c|c|c|c|c|c|c|c|}
\hline \multirow{3}{*}{$\begin{array}{l}\mathbf{N} \\
\mathbf{0}\end{array}$} & \multirow{3}{*}{$\begin{array}{l}\text { Bahan } \\
\text { Pakan }\end{array}$} & Komposi & \multicolumn{8}{|c|}{ Kandungan Zat Gizi dalam Bahan Pakan* } \\
\hline & & & \multicolumn{4}{|c|}{ Proksimat } & \multicolumn{2}{|c|}{ Asam Amino } & \multicolumn{2}{|c|}{ Mineral } \\
\hline & & & $\begin{array}{l}\text { Protei } \\
\text { n }\end{array}$ & EM & SK & $\begin{array}{l}\text { Lema } \\
\mathbf{k}\end{array}$ & Meth & Lis & $\mathbf{C a}$ & $\mathbf{P}$ \\
\hline & & $\%$ & $\%$ & $\%$ & $\%$ & $\%$ & $\%$ & $\%$ & $\%$ & $\%$ \\
\hline 1 & Jagung & 29 & 2,61 & 991,8 & 0,58 & 1,102 & $\begin{array}{c}0,060 \\
9\end{array}$ & $\begin{array}{c}0,098 \\
6\end{array}$ & $\begin{array}{c}0,008 \\
7\end{array}$ & $\begin{array}{c}0,075 \\
4\end{array}$ \\
\hline 2 & $\begin{array}{l}\text { Dedak } \\
\text { halus }\end{array}$ & 35 & 3,15 & 407,5 & 2,63 & 2 & $\begin{array}{c}0,087 \\
5\end{array}$ & 0,145 & 0,03 & $\begin{array}{c}0,377 \\
5\end{array}$ \\
\hline 3 & $\begin{array}{l}\text { Bungki } \\
1 \\
\text { Kelapa }\end{array}$ & 15 & 3,15 & 273 & 1,73 & 1,05 & 0,051 & $\begin{array}{c}0,070 \\
5\end{array}$ & $\begin{array}{c}0,031 \\
5\end{array}$ & $\begin{array}{c}0,097 \\
5\end{array}$ \\
\hline 4 & $\begin{array}{l}\text { Tepung } \\
\text { Ikan }\end{array}$ & 10 & 5,5 & 289 & 0 & 0,6 & 0,151 & 0,462 & 0,581 & 0,323 \\
\hline 5 & Sagu & 10 & 2,1 & 263 & $\begin{array}{c}0,46 \\
8\end{array}$ & 0 & 0 & 0 & 0,05 & 0,15 \\
\hline 6 & $\begin{array}{l}\text { Molase } \\
\mathrm{s}\end{array}$ & 10 & 0,31 & 529,1 & 0,06 & 0,09 & & & 0,15 & 0,002 \\
\hline 7 & $\begin{array}{l}\text { Minera } \\
1 \text { Itik }\end{array}$ & 0,5 & & & & & & & & \\
\hline 8 & Garam & 0,5 & & & & & & & & \\
\hline & MLAH & 100 & 16,82 & $\begin{array}{c}2753 \\
4 \\
\end{array}$ & $\begin{array}{c}5,45 \\
8 \\
\end{array}$ & 5,342 & $\begin{array}{c}\mathbf{0 , 3 5 0} \\
\mathbf{4} \\
\end{array}$ & $\begin{array}{c}0,776 \\
1 \\
\end{array}$ & $\begin{array}{c}\mathbf{0 , 8 5 1} \\
2 \\
\end{array}$ & $\begin{array}{c}1,025 \\
4\end{array}$ \\
\hline
\end{tabular}

Sumber : Berdasarkan tabel kandungan nutrisi pakan (Hartadi et al.,1997)

Berdasarkan tabel kandungan nutrisi pakan (NRC 1994.)

\section{RancanganPenelitian}


Rancangan penelitian yang digunakan adalah Rancangan Acak Lengkap (completely randomized design) terdiri dari 4 perlakuan dan 4 ulangan. Setiap ulangan merupakan unit percobaan yang terdiri dari 5 ekor itik. Perlakuan yang diberikan adalah pakan fermentasi probiotik yang ditambahkan ke dalam ransum basal.

Model matematispenelitian yang digunakanmenurut Steel danTorrie (1993) adalah:

Keterangan:

$$
\mathrm{Y}_{\mathrm{ijk}}=\mu+\alpha_{\mathrm{j}}+\varepsilon_{\mathrm{ij}}
$$

$\mathrm{Y}_{\mathrm{ijk}} \quad$ : Nilaipengamatan

$\mu \quad$ : Nilaitengahumum

$\alpha_{\mathrm{ij}} \quad$ : Pengaruhperlakuanpemberianransum

$\varepsilon_{\mathrm{ij}} \quad$ : Galatperlakuanke-i, ulanganke-j

Tabel 1.BaganRancanganPenelitian

\begin{tabular}{ccccc}
\hline Ulangan & \multicolumn{4}{c}{ Perlakuan } \\
\cline { 2 - 5 } & $\mathrm{R} 1$ & $\mathrm{R} 2$ & $\mathrm{R} 3$ & $\mathrm{R} 4$ \\
\hline 1 & $\mathrm{R} 1.1$ & $\mathrm{R} 2.1$ & $\mathrm{R} 3.1$ & $\mathrm{R} 4.1$ \\
2 & $\mathrm{R} 1.2$ & $\mathrm{R} 2.2$ & $\mathrm{R} 3.2$ & $\mathrm{R} 4.2$ \\
3 & $\mathrm{R} 1.3$ & $\mathrm{R} 2.3$ & $\mathrm{R} 3.3$ & $\mathrm{R} 4.3$ \\
4 & $\mathrm{R} 1.4$ & $\mathrm{R} 2.4$ & $\mathrm{R} 3.4$ & $\mathrm{R} 4.4$ \\
\hline
\end{tabular}

Ket : $\mathrm{R}_{1}=$ Ransum basal (kontrol)

$\mathrm{R}_{2}=$ Ransum fermentasi probiotik $10 \mathrm{ml} /$ liter air

$\mathrm{R}_{3}=$ Ransum fermentasi probiotik 12,5 ml/liter air

$\mathrm{R}_{4}=$ Ransum fermentasi probiotik $15 \mathrm{ml} /$ liter air

\section{Parameter Penelitian}

Parameter yang diamati dalam penelitian ini meliputi:

1. Bobot akhir itik Peking

Data bobot badan akhir diperoleh hasil akhir penimbangan setelah umur itik Peking 60 hari, melalui penimbangan seluruh itik kemudian dirata-ratakan.

2. Bobot karkas itik Peking

Data bobot karkas diperoleh dengan menimbang setelah itik Peking dipotong pada daerah persendian atas dari tulang leher dan darah dikeluarkan, tidak termasuk kepala, leher, bulu, kaki bagian bawah mulai dari sendi tarsometa tarsus serta seluruh alat jeroan.

3. Persentase karkas

Data persentase karkas diperoleh dengan memakai rumus sebagai berikut :

$$
\frac{\text { bobot karkas }}{\text { bobot hidup }} \times 100 \%
$$

4. Bobot potongan karkas (dada, sayap, paha, dan punggung).

5. Persentase potongan karkas (dada, sayap, paha, dan punggung)

Persentase potongan karkas diperoleh dengan cara membagi bobot potongan karkas (dada, sayap, paha, dan punggung) dengan bobot karkas kemudian dikalikan $100 \%$ (Soeparno,1994).

\section{Analisa Data}


Data yang diperoleh dianalisis dengan Analysis of Variance (ANOVA). Jika dari analisis tersebut didapatkan hasil yang berbeda nyata, maka dilanjutkan dengan uji Duncan (Steel dan Torrie, 1993).

\section{HASIL DAN PEMBAHASAN}

\section{Pengaruh Perlakuan Terhadap Berat dan Persentase Karkas}

Pengaruh pemberian pakan fermentasi probiotik dalam ransum terhadap berat dan persentase karkas itik Peking pada minggu ke delapan dapat dilihat pada Tabel 3.

Tabel 2. Rataan Berat Hidup, Berat Karkas dan Persentase Karkas Itik Peking (g/ekor).

\begin{tabular}{llllll}
\hline \multirow{2}{*}{ Parameter } & \multicolumn{4}{c}{ Perlakuaan } \\
\cline { 2 - 6 } & \multicolumn{1}{c}{ R1 } & \multicolumn{1}{c}{ R2 } & \multicolumn{1}{c}{ R3 } & \multicolumn{1}{c}{ R4 } \\
\hline $\begin{array}{l}\text { Berat } \\
\text { (g) }\end{array}$ & Hidup & $1602,5 \pm 67,52$ & $1655,0 \pm 118,5$ & $1730,0 \pm 256,52$ & $1291,3 \pm 654,29$ \\
$\begin{array}{l}\text { Berat } \\
\text { (g) }\end{array}$ & Karkas & $828,75 \pm 31,19$ & $891,25 \pm 25,94$ & $903.75 \pm 87,59$ & $877,31 \pm 21.02$ \\
Karkas (\%) & $51,67 \pm 0,31$ & $53,99 \pm 2,79$ & $52,51 \pm 2,56$ & $54,06 \pm 2,67$ \\
\hline
\end{tabular}

Dari Tabel 3 dapat dilihat bahwa penggunaan pakan fermentasi probiotik dalam ransum memberikan pengaruh yang tidak berbeda nyata terhadap berat hidup, berat karkas dan persentase karkas itik Peking. Hasil sidik ragam (Lampiran 1 - 3) terlihat bahwa penggunaan ransum fermentasi probiotik tidak memberikan pengaruh yang nyata antar perlakuan, meskipun hasil perlakuaan tidak berbeda nyata terhadap berat hidup itik Peking, namun pada Tabel 3 dapat dilihat adanya indikasi bahwa penggunaan ransum fermentasi cenderung lebih tinggi berat hidup dan berat karkas itik Peking (1730 gram dan 903.75 gram) dibandingkan dengan perlakuan yang diberikan ransum kontrol (1602,5 dan 828,75 gram) namun secara statistik tidak menunjukkan perbedaan yang signifikan. Perbedaan ini mungkin disebabkan oleh kandungan nutrisi ransum perlakuan.

Rasyaf (1994) menyatakan bahwa berat badan dapat dipengaruhi oleh kualitas dan kuantitas pakan yang dikonsumsi. Hal ini sesuai dengan pendapat Zahra (1996) yang menyatakan bahwa tingkat konsumsi pakan erat hubungannya dengan pertumbuhan, semakin banyak pakan yang dikonsumsi semakin tinggi pertambahan bobot badan yang dihasilkan sehingga mempercepat pertumbuhan. Pakan yang diberikan sangat mempengaruhi pertumbuhan untuk ternak. Hal ini didukung oleh pendapat Untung (2007) efisiensi pemberian pakan memiliki hubungan yang nyata dengan kualitas dan jumlah pakan, yaitu semakin tinggi kualitas dan konsumsi pakan akan menghasilkan efisiensi pemberian pakan yang semakin tinggi pula, sehingga pertumbuhan meningkat.

Jika dilihat kandungan nutrisi ransum perlakuan (Tabel 1), kandungan EM dan protein ransum relatif sama dimana kedua kandungan ini sangat mempengaruhi pertumbuhan itik. Tillman etal., (1991) menyatakan bahwa protein dalam pakan merupakan salah satu faktor yang mempengaruhi bobot karkas itik. Protein adalah suatu zat makanan yang diperlukan untuk pertumbuhan dan jaringan, persentase kandungan protein yang hampir sama pada masing-masing perlakuan merupakan salah satu penyebab berat dan persentase karkas itik 
pedaging tidak berbeda nyata. Energi merupakan salah satu zat makanan yang juga berpengaruh terhadap bobot karkas selain protein. Energi diperlukan sebagai sumber kekuatan untuk hidup dan berproduksi (Jull, 1979). Persentase kandungan energi yang hampir sama pada masing masing perlakuan merupakan salah satu penyebab berat dan persentase karkas itik pedaging tidak berbeda nyata.

Menurut Soeparno (2005) bahwa berat akhir dipengaruhi oleh pertambahan bobot badan dan umur ternak, sedangkan pertambahan bobot badan dipengaruhi oleh asupan nutrien dan pencernaan didalam tubuh ternak. Dimana semakin baik pencernaan dan penyerapan nutrien maka akan memberikan pertambahan bobot badan yang semakin baik dan secara langsung memberikan pengaruh terhadap bobot potong. Seifer dan Gesler (1997) menyatakan bahwa penggunaan probiotik pada ternak bertujuan untuk memperbaiki kondisi saluran pecenaan dan menekan reaksi pertumbuahan racun dan metabolit yang bersifat karsinogenik, dan meransang reaksi enzim yang dapat menetralisir senyawa racun yang tertelan atau dihasilkan oleh saluran pencernaan.

Hasil penelitian terhadap bobot karkas menunjukkan bahwa bobot karkas yang paling rendah $828,75 \pm 31,19$ gram dan paling tinggi $903.75 \pm 87,59$ gram. (Tabel 3) hasil penelitian diperoleh berat karkas itik Peking pada perlakuan kontrol $\left(\mathrm{R}_{1}\right)$ dengan bobot karkas sebesar 828,75 $\pm 31,19$ gram, perlakuan $\mathrm{R}_{2}$ dengan bobot karkas sebesar 891,25 $\pm 25,94$ gram, perlakuan $\mathrm{R}_{3}$ dengan bobot karkas $903.75 \pm 87,59$ gram, perlakuan $\mathrm{R}_{4}$ dengan bobot karkas 877,31 \pm 21.02 gram. Rataan bobot karkas dalam penelitian ini cenderung meningkat pada perlakuan $\mathrm{R}_{2}, \mathrm{R}_{3}$ dan $\mathrm{R}_{4}$ dibandingkan dengan perlakuan $\mathrm{R}_{1}$ (kontrol). Hal ini dikarenakan tingkat konsumsi pakan yang berbeda pada setiap perlakuan sehingga bobot badan yang dihasilkan berbeda pula, dan ini menyebabkan bobot karkas yang dihasilkan juga berbeda hal ini sesuai dengan pendapat Gunawan and Sunandari. (2003) yang menyatakan bahwa berat karkas dipengaruhi oleh berat hidup, semakin tinggi berat hidup semakin tinggi pula berat karkasnya.

Hasil penelitian persentase karkas itik Peking pada akhir minggu kedelapan tertinggi dihasilkan pada perlakuan $\mathrm{R}_{4}$ sebesar 54,06 $\pm 2,67$ disusul perlakuan $\mathrm{R}_{2}$ $(53,99 \pm 2,79 \%), \mathrm{R}_{3}(52,51 \pm 2,56 \%)$, dan perlakuan terendah pada perlakuan $\mathrm{R}_{1}$ sebesar $51,67 \pm 0,31 \%$. Persentase karkas cenderung meningkat pada perlakuan $\mathrm{R}_{2} \mathrm{R}_{3}$ dan $\mathrm{R}_{4}$ dibandingkan dengan $\mathrm{R}_{1}$ (kontrol). Hasil analisa sidik ragam (Lampiran 3) menunjukkan bahwa ransum fermentasi probiotiktidak menunjukkan perbedaan yang nyata terhadap persentase karkas itik Peking. Hal ini disebabkan selain dipengaruhi oleh bobot hidup, persentase karkas juga dipengaruhi oleh bobot non karkas dan bagian yang terbuang. Hal ini sesuai dengan pendapat Soeparno (1998) yang menyatakan persentase karkas di pengaruhi oleh faktor kualitas ransum dan laju pertumbuhan ternak. Dimana laju pertumbuhan ternak ditunjukkan dengan adanya pertambahan bobot badan dan dipengaruhi oleh bobot potong yang dihasilkan, bobot potong akan berpengaruh pada persentase karkas yang dihasilkan. Menurut Daryantietal.,(1982) dan Wahidayatun (1983) yang menyatakan bahwa persentase karkas dipengaruhi oleh besarnya persentase bagian tubuh yang terbuang serta bagian tubuh diluar karkas. Itik peking pada hasil penelitian ini pada kisaran normal. Sastroamidjojo (1990) mengatakan bahwa persentase karkas pada umumnya berkisar antara 50 sampai 60 persen. 


\section{Pengaruh Ransum Perlakuan Terhadap Berat Potongan Karkas}

Pengaruh pemberian ransum fermentasi probiotik terhadap berat potongan karkas itik Peking pada akhir minggu ke delapan dapat dilihat pada Tabel 5.

Tabel 3. Rataan Potongan Karkas (Dada, Sayap, Paha dan Punggung) Itik Peking (g/ekor)

\begin{tabular}{lllll}
\hline \multicolumn{1}{c}{ Potongan } & \multicolumn{4}{c}{ Perlakuan } \\
\cline { 2 - 5 } \multicolumn{1}{c}{ Karkas } & \multicolumn{1}{c}{ R1 } & \multicolumn{1}{c}{ R2 } & \multicolumn{1}{c}{ R3 } \\
\hline Dada $(\mathrm{g})$ & $195.00 \pm 31,09$ & $203,76 \pm 12,50$ & $218.75 \pm 34,73$ & $200.00 \pm 14,72$ \\
Sayap $(\mathrm{g})$ & $126,25 \pm 12,50^{\mathrm{a}}$ & $165,00 \pm 7,07^{\mathrm{b}}$ & $168,76 \pm 11,82^{\mathrm{b}}$ & $176,26 \pm 22,87^{\mathrm{b}}$ \\
Paha $(\mathrm{g})$ & $212,5 \pm 26,30$ & $187,50 \pm 6,46$ & $181,25 \pm 26,58$ & $177,50 \pm 6,46$ \\
Punggung (g) & $295,00 \pm 36,29$ & $323,76 \pm 17,97$ & $320.00 \pm 27,39$ & $320.00 \pm 10,80$ \\
\hline
\end{tabular}

Keterangan : Superkrip yang berbeda pada kolom yang sama menunjukkan berpengaruh sangat nyata $(\mathrm{P}<0,01)$

\section{Bobot Potongan Karkas Dada}

Dada merupakan potongan komersial yang banyak mengandung daging, bagian dada memiliki daging yang sangat empuk dan sedikit mengandung lemak. Rataan bobot dada itik Peking dari masing masing perlakuan dapat dilihat pada Tabel 4. Hasil sidik ragam (Lampiran 4) menunjukkan bahwa pemberian pakan fementasi probiotik yang berbeda tidak menunjukkan perbedaan yang nyata terhadap bobot dada itik Peking. Hasil penelitian ini menunjukkan bahwa rataan bobot potongan dada itik Peking pada $\mathrm{R}_{1} 195.00 \pm 31,09, \mathrm{R}_{2} 203,76 \pm 12,50, \mathrm{R}_{3}$ $218.75 \pm 34,73$, dan $R_{4} 200.00 \pm 14,72$. Hasil penelitian ini lebih kecil dari hasil penelitian Lestari (2011), yaitu berat bobot dada sebesar 260,22 gram dan 31,88\% pada itik Alabio jantan pada umur 10 minggu. Hal diduga disebabkan karena imbangan serat kasar dengan protein dalam pakan kurang seimbang. Menurut Manin (1997) meningkatnya taraf serat kasar dalam ransum akan menurunkan kecernaan zat makanan, sehingga imbangan energi dan protein yang diserap tubuh menurun, penurunan imbangan energi dan protein menyebabkan pembentukan komponen tubuh berkurang, akibatnya semakin tinggi serat kasar dalam ransum menyebabkan berat dan persentase dada menurun, karena dada itik memiliki pertumbuhan yang heteregonik yang secara ilmiah disebabkan faktor genetik (Natasasmita, 1990) maka kecepatan penurunan bobot dada lebih tinggi dari pada karkas, sehingga semakin kecil bobot karkas maka semakin kecil pula persentase dada.

\section{Berat potongan karkas Sayap}

Pemberian pakan fermentasi probiotik berbeda sangat nyata $(P<0,01)$ terhadap berat sayap. Hasil uji lanjut Duncan menunjukkan bahwa $\mathrm{R}_{1}$ sangat berbeda nyata $(\mathrm{P}<0,01)$ dengan $\mathrm{R}_{2}, \mathrm{R}_{3}, \mathrm{R}_{4}$.. Pakan fermentasi dengan level probiotik yang berbeda menghasilkan potongan sayap karkas itik Peking pada akhir minggu ke delapan meningkat berat bobot potongan karkas dibandingkan dengan perlakuan ransum tanpa fermentasi. Basoeki (1983) menyatakan bahwa sayap merupakan bagian karkas yang lebih banyak mengandung jaringan tulang dibandingkan dengan jaringan otot, sehingga lebih berpengaruh adalah mineral dalam ransum untuk pertumbuhan ternak.

Hasil penelitian ini lebih tinggi dari penelitian Randa (2002) yang menyatakan bahwa rataan berat sayap itik mandalung pada umur 10 minggu sebesar 147,51 gram. Anggorodi(1985) menyatakan bahwa pertumbuhan jaringan 
tulang dan daging sangat tergantung pada ketersediaan protein pakan. Protein khususnya asam amino yang berfungsi untuk membentuk jaringan otot.

\section{Bobot Potongan KarkasPaha}

Rataan bobot paha pada masing-masing perlakuan dapat dilihat pada Tabel 4. Hasil sidik ragam (Lampiran 6) menunjukkan bahwa pemberian ransum fermentasi probiotik tidak berpengaruh nyata terhadap bobot paha itik Peking. Rataan berat paha itik Peking masing masing perlakuan yaitu $R_{1}$ sebesar 212,5 gram, $R_{2}$ sebesar 187,50 gram, $R_{3}$ sebesar 181,25 gram, dan $R_{4}$ sebesar 177,50 gram, meskipun perlakuan kontrol lebih besar dari $R_{2}, R_{3}$, dan $R_{4}$ namun secara statistik tidak menunjukkan perbedaan yang nyata terhadap bobot paha itik Peking. Hasil penelitian ini lebih rendah dari penelitian Lestari (2011) berat bobot itik Alabio umur 10 minggu sebesar 187,13 gram. Pertumbuhan sangat dipengaruhi oleh asupan nutrisi (pakan), umur, galur, jenis kelamin dan penyakit serta laju pertumbuhan merupakan sifat yang diturunkan (terkait genetik) dan sangat dipengaruhi oleh asupan nutrisi dan lingkungan (Ensminger, 1992). Menurut Hayse dan Morion (1973) secara umum faktor utama yang menentukan variasi hasil daging adalah ukuran, jenis kelamin, konformasi tubuh dan genetik unggas. Selanjutnya Setioko et al.,(2002) menyatakan bahwa pertumbuhan itik sangat dipengaruhi oleh pakan yang dikonsumsi, lingkungan sekitar, sistem perkandangan dan potensi genetiknya.

\section{Berat Potongan KarkasPunggung}

Pemberian ransum fermentasi probiotik tidak berpengaruh nyata terhadap bobot punggung itik Peking (Tabel 4). Hasil penelitian menunjukkan bahwa bobot punggung itik Peking yang diberikan ransum fermentasi probiotik lebih tinggi bobot potongan karkas punggung dari pada berat karkas tanpa menggunakan ransum fermentasi. Suharto (1995) menyatakan bahwa dengan penambahan probiotik starbio ke dalam ransum ternak dapat mengakibatkan terjadinya penguraian zat gizi menjadi komponen yang lebih sederhana dan mudah diserap secara langsung. Meskipun secara kuantitatif tidak menyebabkan terjadinya peningkatan bobot badan.

\section{Pengaruh Ransum Perlakuan Terhadap Persentase Potongan Karkas}

Hasil penelitian pengaruh pemberian ransum fermentasi probiotik terhadap persentase potongan karkas itik Peking pada minggu kedelapan dapat dilihat pada Table 4.

Tabel 4.Rataan Persentase Potongan Karkas (Dada, Sayap, Paha, Punggung) itik Peking (g/ekor)

\begin{tabular}{llllll}
\hline Persentase Karkas & \multicolumn{5}{c}{ Perlakuan } \\
\cline { 2 - 5 } & R1 & R2 & R3 & R4 \\
\hline
\end{tabular}




\begin{tabular}{lllll}
\hline Dada (\%) & $24,92 \pm 1,78$ & $22,85 \pm 0,85$ & $24,11 \pm 1,55$ & $22,78 \pm 1,29$ \\
Sayap (\%) & $16,32 \pm 2,3^{\mathrm{a}}$ & $18,51 \pm 0,46^{\mathrm{b}}$ & $18,71 \pm 0,73^{\mathrm{b}}$ & $18,95 \pm 0,18^{\mathrm{b}}$ \\
Paha (\%) & $27,73 \pm 6,42^{\mathrm{b}}$ & $21,06 \pm 1,13^{\mathrm{a}}$ & $19,99 \pm 1,05^{\mathrm{a}}$ & $20,23 \pm 0,68^{\mathrm{a}}$ \\
Punggung (\%) & $38,48 \pm 8,80$ & $36,32 \pm 1,64$ & $35,44 \pm 0,82$ & $36,47 \pm 0,97$ \\
\hline
\end{tabular}

Keterangan: Superskrip yang berbeda pada baris yang sama menunjukan berpengaruh nyata $(\mathrm{P}<0,05)$

\section{Persentase Karkas Dada}

Dari hasil penelitian persentase karkas bagian dada itik Peking pada umur 8 minggu diperoleh rataan persentase dada sebesar $R_{1} 24,92 \pm 1,78 \%, R_{2}$ $22,85 \pm 0,85, R_{3} 24,11 \pm 1,55, R_{4} 22,78 \pm 1,29$ (Tabel 5). Hasil sidik ragam menunjukkan bahwa pemberian ransum fermentasi probiotik dengan level berbeda tidak memberikan pengaruh yang nyata terhadap persentase dada itik Peking pada umur 8 minggu. Meskipun tidak berbeda nyata perlakuan $R_{2}, R_{3}$, dan $\mathrm{R}_{4}$ yang diberikan ransum fermentasi probiotik ada kecenderungan lebih tinggi persentase dada dari pada ransum kontrol $\left(\mathrm{R}_{1}\right)$. Menurut Anggraeni (1999) pertumbuhan bagian dada relatif konstan hingga umur 12 minggu. Persentase dada pada itik relatif tinggi karena dada merupakan komponen yang masak lambat. Hasil penelitian ini menunjukkan lebih tinggi dari penelitian yang dikemukakan Leclerq dan de Carville (1985) bahwa persentase dada itik jantan umur 10 minggu adalah 11,2 persen. Itik lokal jantan hasil penelitian memiliki persentase dada yang lebih tinggi karena adanya perbedaan strain, pakan dan lingkungan yang digunakan.

\section{Persentase KarkasSayap}

Hasil dari penelitian menunjukkan rataan persentase sayap itik Peking dari masing masing perlakuan dapat di lihat pada Tabel 5. Hasil sidik ragam (Lampiran 9) menunjukkan bahwa pemberian ransum fermentasi probiotik dalam ransum itik peking berpengaruh nyata $(\mathrm{P}<0,05)$ antar perlakuan. Hasil uji lanjut Duncan menunjukkan bahwa $\mathrm{R}_{1}$ berbeda nyata $(\mathrm{P}<0,05)$ dengan $\mathrm{R}_{2}, \mathrm{R}_{3}, \mathrm{R}_{4}$, hal ini menunjukkan bahwa penggunaan ransum fermentasi lebih baik dibandingkan tanpa ransum fermentasi, karena menghasilkan berat sayap yang lebih tinggi. Sementara itu rataan persentase sebesar sayap sebesar $R_{1} 16,32, R_{2} 18,51, R_{3}$ 18,71, dan $\mathrm{R}_{4}$ 18,95, Persentase ini lebih tinggi dibandingkan dengan hasil penelitian Nugraha (2000) pada itik Mojosari jantan umur 10 minggu, yaitu sebesar 16,33\%. Anggraeni (1999) memperoleh persentase sayap pada itik lokal jantan umur 12 minggu sebesar $17,50 \%$.

\section{Persentase Karkas Paha}

Pemberian ransum fermentasi probiotik berpengaruh nyata $(\mathrm{P}<0,05)$ terhadap berat persentase paha itik peking. Hasil uji lanjut Duncan menunjukkan bahwa $R_{1}$ berbeda nyata $(P<0,05)$ terhadap $R_{2}, R_{3}$ dan $R_{4}$, yang menggunakan level probiotik yang meningkat dari 10 sampai $15 \mathrm{ml}$. Paha merupakan salah satu bagian potongan karkas komersial. Paha utuh terdiri dari dua bagian, yaitu paha bagian atas dan paha bagian bawah. MenurutNatasasmita (1990) pahapadaitikmenunjukkankecepatanperkembangan samadengantubuhsecarakeseluruhan, dengan kata lain pahamempunyaipolapertumbuhanisogonik. Pada penelitian ini persentase berat 
paha diukur secara utuh tanpa dipisahkan menjadi paha bagian atas dan bawah. Persentase karkas paha pada penelitian ini lebih kecil dari hasil penelitian Angeraini (1999) yaitu sebesar 32,47 \% pada itik lokal umur 12 minggu. Soeparno (1998) menyatakan bahwa faktor-faktor yang dapat mempengaruhi persentase karkas suatu ternak terdiri atas bangsa, kondisi fisik, bobot badan dan pakan.

\section{Persentase Karkas Punggung}

Hasil dari penelitian menunjukkan bahwa Pemberian ransum fermentasi probiotik tidak berpengaruh nyata terhadap persentase karkas punggung. Punggung merupakan bagian yang didominasi oleh tulang, selama pertumbuhan tulang tumbuh secara kontinu dengan kadar laju pertumbuhan relatif lambat. Ratarata persentase punggung yang dihasilkan lebih tinggi dari penelitian Moutney (1966) yang disitasi Hadiwiyoto (1992) menyatakan bahwa persentase punggung itik jantan pada umur 7,5 minggu adalah 23 persen. Basoeki (1983) menyatakan bahwa punggung banyak mengandung jaringan tulang, sehingga yang lebih berpengaruh adalah mineral ransum untuk masa pertumbuhannya. Ini diduga karena pakan yang dikonsumsi oleh itik banyak mengandung mineral, sehingga jaringan tulang tumbuh dengan baik

\section{KESIMPULAN DAN SARAN}

\section{Kesimpulan}

Berdasarkan hasil penelitian yang telah dilakukan maka dapat disimpulkan bahwa penggunaan ransum fermentasi probiotik tidak memberikan pengaruh negatif terhadap berat karkas itik Peking dan mampu meningkatkan persentase karkas dan potongan karkas itik Peking umur 8 minggu.

\section{Saran}

Berdasarkan hasil penelitian yang telah dilakukan dapat diberikan saran sebagai berikut:

1. Bagi peternak khususnya itik Peking sebaiknya memberikan ransum fermentasi probiotik dengan level 12,5 ml/liter air

2. Perlu dilakukan penelitian lebih lanjut untuk itik Peking terutama yang menyangkut tentang karkas.

\section{DAFTAR PUSTAKA}

Anggorodi, R. 1985. Kemajuan Mutakhir dalam Ilmu Makanan Ternak Unggas.Universitas IndonesiaPress. Jakarta. 
Anggraeni. 1999. Pertumbuhan alometri dan tinjauan morfologi serabut otot dada (Muscullus pectoralis dan Muscullus supracorarideus) pada itik dan entok lokal. Tesis. Program Pascasarjana Institut Pertanian Bogor, Bogor.

Basoeki, B. D. A. 1983. Pengaruh Tingkat Pemberian Ampas Tahu dalam Ransum terhadap Potongan Karkas Komersial Ayam Broiler Betina Strain Hybro Umur 6 Minggu.Skripsi.Fakultas Peternakan. Institut Pertanian Bogor. Bogor.

Daryanti, Baihaqi A dan R. Herman.1982. Perbandingan Produksi Daging AntaraAyam Jantan Petelur dan Ayam Jantan Pedaging.Media Peternakan. FakultasPeternakan. Institut Pertanian Bogor, Bogor.

Ensminger, M. A. 1992. Poultry Science (Animal Agiculture Series). 3th Edition.Interstate Publisher, Inc. Danville, Illionis.

Lestari, 1992.Menentukan Bibit Broiler Peternakan Indonesia. Pt Gramedia,Jakarta.

Lestari, F. E. P. 2011. Persentase Karkas, Dada, Paha dan Lemak Abdomen Itik Alabio Jantan Umur 10 Minggu yang Diberi Tepung Daun Beluntas, Vitamin C dan E dalam Pakan. Skripsi. Jurusan Ilmu Produksi Dan Teknologi Peternakan. Fakultas Peternakan. Institut Pertanian Bogor. Bogor.

Manin, F. 1997. Penggunaan Tepung Enceng Gondok (Eichorama crassipies mart) dan Azola (Azolla pinnata brown) dalam Ransum Itik Periode Pertumbuhan.Jurnal Peternakan dan Lingkungan. 3(2) : 13-20

Moran, E.T. 1999. Live Production Factors Influencing Yield and Quality of Poultry MeatScience. CAB International. England.

Murtidjo, B.A. 1987. Pedoman Beternak Ayam Broiler.Kanisius. Yogyakarta.

Murtidjo, B.A. 1998. MengelolaItik. Kanisius. Yogyakarta.

Natasasmita, A. 1990.Tumbuh Kembang pada Ternak.Buletin Penelitian Universitas Djuanda Bogor. 1 (1) : 45-50.

NRC. 1994. Nutrient Requirements of Poultry. National Academy Press. Washington, DC.

Randa, S. Y., I. Wahtuni, G. Joseph, H. Triely Uhy, Rukmiasih, H. Hafid dan A. Parakkasi. 2002. Efek Pembeian Serat Tinggi dan Vitamin-E Terhadap Produksi Karkas dan Non Karkas Itik Madalung. Jurnal Seminar Nasional Teknologi Peternakan dan Veteriner 2002. Laboratorium Nutrisi Ternak Daging dan Kerja. Fakultas Peternakan. Institut Pertanian Bogor. Bogor.

Rasyaf,M.1990. Bahan Makanan Unggas Di Indonesia Kanisius Yogyakarta Rasyaf, M. 1994. Seputar Makanan Ayam Kampung. Kanisus.Yogyakarta.

Rasyaf,M 2004. Bahan Makanan Unggas Di Indonesia Kanisius Yogyakarta Setioko, A.R., P. Situmorang, E. Triwulaningsih, T. Sugiartidan D.A.

Kusumaningrum. 2002.

Pengaruhkrioprotektandanwaktuekuilibrasiterhadapkualitasdanfertilitas spermatozoa itikdanentok. JITV: 237-243.

Soeparno. 1994. Ilmu dan Teknologi Daging. Gadjah Mada University Press, Yogyakarta. 
Soeparno.1998.Ilmu Dan Teknologi Daging. Gadjah Mada University Press, Yogyakarta

Soeparno,2005.Ilmu Dan Teknologi Daging .Edisi 4.Gajah Mada University Press Yogyakarta.

Standar Nasional Indonesia.2009. Mutu Karkas dan Daging Ayam. SNI 3924:2009. Badan Standarisasi Nasional. Jakarta.

Suharto dan Winantuningsih. 1995. Pemanfaatan Probiotik Dalam Pakan Untuk Meningkatkan Efisiensi Produksi Ternak di Pedesaan. Prosiding Pertemuan Ilmiah Komunikasi dan Penyaluran Hasil Penelitian Buku I. Badan Penelitian Pengembangan Pertanian, Bandungan Semarang.

Steel. R.G.D. and J.H. torrie.1993. Prinsip Dan Prosedur Statistka: Suatu Pendekatan Biometrik. Penerbit PT Gramedia Pustaka Utama Jakarta.

Tillman, A. D., H. Hartadi, S. Reksohadiprodjo, S. Prawirokusumo dan S. Lebdosoekojo. 1991. Ilmu Makanan Ternak Dasar. UGM Press, Yogyakarta.

Tillman, A. D., H. Hartadi, S. Reksohadiprojo, S. Prawirokusumo dan S.Lebdosoekojo. 1998. Ilmu Makanan Ternak Dasar. Gadjah Mada University Press, Yogyakarta.

Untung K, A. A. M, K. Haetami dan Y. Mulyani. 2007. Penggunaan Limbah Kiambang Jenis Duckweeds dan Azola Dalam Pakan dan Implikasinya Pada Ikan Nilem. Lembaga Penelitian Universitas Padjadjaran. Bandung.

wahidayatun, 1993. Kajian Tingkat Kenyamanan Itik yang Dipelihara Secara Gembala dan Terkurung. Laporan Hasil Penelitian. Fakultas Peternakan. Universitas Jenderal Soedirman. Purwokerto. 